\title{
Challenging State Loss Element on Corruption Offenses from the Administration Law Perspective
}

\author{
KartikaWidya Utama ${ }^{1}$ and Yos Johan Utama ${ }^{2}$ \\ \{kartikawidyautama@yahoo.co.id ${ }^{1}$,yosjohanutama@yahoo.com² ${ }^{2}$, \\ Diponegoro University, J1.Prof.H.Soedarto, S.H., Tembalang, Tembalang, Kota Semarang, Jawa \\ Tengah 50275 Indonesia
}

\begin{abstract}
Post-reform 1998, corruption remains the main problem in Indonesia. The abundant natural resources and human resources cannot be put to good use because of the many corruption cases in Indonesia. However, not all cases of corruption occur because of the intention of the perpetrators, but it occurred because of misunderstanding in measuring elements of state losses, both at the level of investigation to prosecution. Verdict MK No. 25 / PUU-XIV / 2016 abolishes the word "can" in Article 2 paragraph 1 of the Corruption Act makes the formulation of corruption offense into material offense rather than formal offense. So that all elements contained in the formulation of the offense must be proven first. This makes understanding of the element of state loss more critical than ever. This article will attempt to explain when the state losses occur and the legal consequences of the own state losses. This article will also provide a new perspective in understanding the loss of the state from the administrative side of government. That there is no crime without errors, making the fault of state administrative officials must precede the element of the loss in this country in exercising their authority. Indonesia, as a country that embraces multi-system jurisdiction, divides the powers of the courts in separate Courts. Therefore, the differences in the existence of elements of abuse of authority also become a debate between Judicial Bodies. This difference of perception must be put together first so that it is not expected to happen injustice due to the difference of perception and then put harm to society.
\end{abstract}

Keywords: Corruption Offenses, State Loss, Administration Law

\section{Introduction}

After 19 years, corruption still becomes Indonesia's biggest enemy besides poverty. The rise of corruption cases that occurred in Indonesia has hampered the aspirations of the Indonesian nation to prosper the people. The spirit of prospering the people after Reformation in 1998 has resulted in Law no - 32 of 2004 on Regional Government. The formerly centralized government was changed to decentralization in the regions, with the expectation of more informed Local Governments in the area and closer to the location. Lead to immediate and better reach for local people's aspirations. However, sadly, the expected decentralization also brings new problems, believes in the spread of corrupt behavior by local government officials, a tragedy and irony. As Mahmood said in Bangladesh that corruption and poor governance are impeding Bangladesh's efforts to reduce its massive poverty by reducing economic growth and lowering the achievement of social objectives. [1] The case of local financial corruption ranks first from the trend of corruption in Indonesia.

The cause of widespread corruption among the Regional Apparatus is not only due to weak supervision from the center, but also derived from various factors: Inappropriate 
autonomy level, no improvement in real fiscal autonomy, lack of finance source, resource of rich provinces favored, 'Grey areas', Human resource capabilities and inappropriate time scale [2]. This article will focus on the gray areas caused by the disharmony of legislation, especially in the area of state finances related to the state losses[3] as well as incompetence of regional government apparatus, especially the head of the region which is the cause of the rampant corruption cases that exist in the region and involve the Regional Head. This paper will also examine which courts should have the authority and competence in determining whether or not the element of state losses.

In summary, this article will explore some of the problems, the first of which is about the meaning of the state losses by the judiciary, which will discuss what is meant by the state losses under Indonesian law. Second, is the incompetence of Local Government Apparatus in carrying out its duties, causing maladministration which from the perspective of Indonesian law is currently considered as a criminal act of corruption. The third is to provide an argument based on the conclusion of the two answers to the above question about which judiciary should have the authority to state whether or not the state's loss.

\section{Methodology}

This article uses the method of socio-legal studies which is an alternative method of examining doctrinal studies of the law [4] to examine the impact of Article 2 of the Corruption Act and the hermeneutical approach to interpret several articles related to state losses in the Anti-Corruption Act and other related Laws.According to Adler socio-legal paradigm adopt an external perspective to the legal process that seeks to analyze administrative justice in terms of concepts and categories that are derived from the social sciences[5].

\section{Findings}

First, we will discuss uncertainty when defining State Loss in Indonesia Corruption Act. The state losses in Indonesia can be caused by non-compliance with the law in the field of state financial management, which can be on recitative over he instead, detour de pouvoir, and willekeur[6]. In practice, however, it is difficult to determine whether the fault of the state administrative official is an administrative error or a criminal offense. The determination of whether the loss of the state is an administrative error or a criminal offense must be through a legal procedure, which relies heavily on the competence of law enforcement officers, who unfortunately prioritize the fulfillment of offense rather than the usefulness of a state administration policy. There is a corruption case in which the price paid by the agreement and none of the defendants who enjoy/benefit from the action but still found guilty for fulfilling the element of error procedures in the management of state money.

While the law must be able to provide justice, in order to achieve justice, there must be certainty in the preparation up to its implementation. Standards of action and inaction should be clearly stated[7] wrote in his famous work, the principle must be expounded in a manner so that it can be generally applied. A patternless ad hoc system of law lacks the desired "internal morality," which legal principles should possess. In line with Honorestatement, which is moral reasons for conduct can be contrasted with technical or instrumental reason. [8] This proposition is comparable to the often read statement that our government is a government of laws rather than men. This principle followed by 
SatjiptoRahardjo[9] who state that Law is for human, so it must be understood by all of its subject, not just by the law enforcement apparatus. When the law is not clear, the lack of certainty of the interpretation of the law and the way to proof will result in fear and anxiety on the subject of the law. This uncertainty does not only come from the word "can" on article No. 2 of the Corruption Act but also come from the absence of an assessment standard in determining the element of state loss.

The application of state loss calculation methods is often inconsistent, although in general, the deviation is not much different. There is no visible pattern of calculations that can be used as a guide or reference in calculating the financial losses of the state [10]. There are three models of calculation of state losses in material, namely: Comparative Method, Production Cost Method, and Total Loss Method.

The comparative method is subdivided into five types of computations[11]:

a. Comparison between the estimated price itself and the market price. The difference between losses lies in the realization of the overpayment of employment.

b. Comparison of price and quality of government procurement goods with similar apple to apple comparison.

c. Comparison between the realization of work result with quality, volume, and building plan in the contract of work agreement.

d. Comparison of the value, quantity, or volume of goods or work received with the value of the actual proof of payment.

e. Comparison of price realization of a payment transaction of sale of tax object with the realization of paid taxes (land or government buildings)

While Cost Production Method is divided into two i.e., Cost of Production and Cost of Production ++. Cost of Production is used to calculate the cost of production on procurement goods, medicine, equipment. On the other hand, the cost of production ++ is used to calculate the production cost of the company by agreeing. Last one, on total lost method there are three methods of Total Loss, the first is total loss for procurement or work financed by the state; Second is the loss in a manner overall costs incurred in which Costs incurred in the process procurement is a risk of error; Last is the total loss method with exceptions for activities whose goods may be traded.

The five methods above are to calculate the losses that have occurred and not used to calculate the potential losses of the country. According to research by Irawan[11], if the loss is still in the form of potential, then the State Audit Board of the Republic of Indonesia will not report it as a finding to the authorities as alleged criminal acts of corruption. The examination of the potential loss of the country is included in the category of inspection with a specific purpose. Please note, the State Audit Board of the Republic of Indonesia in conducting the examination is divided into three types of examination.

a. Financial Audit

It is examination applied in central government and local government financial reports. BPK RI conducts this financial audit in order to provide opinions on the fairness of the information presented in the financial statements of the government. The audit report on the government's financial statements includes opinions.

b. Performance Check

It is an examination of economic and efficiency and effectiveness did for the interest of management. The purpose of this examination is to identify the things that need to be of concern to the representative body. As for the government, performance inspection is intended for activities financed with state / regional 
finances organized economically and efficiently and meet the targets effectively. The performance audit report contains findings, conclusions, and recommendations.

c. Inspection With Specific Purposes

Individual purpose checks, excluding audits and performance checks. Included in the examination with this specific purpose is the examination of matters relating to finance and investigative investigation. Reports of inspection results with a specific purpose contain conclusions. Nevertheless, the report of potential state losses made by the Supreme Audit Board of the Republic of Indonesia is often used as the basis for law enforcement officers to conduct corruption law enforcement proceedings.

The problem above led us toward the second part of our discussion. Uncertainty about whether or not this element is proven to have taken its toll, it is now tough to find the State Civil Apparatus who wants to be the committee of procurement of goods and services, as a result of the fear being entangled in corruption. This is in line with Okhotskii argument, which is many officeholders employed in the state and municipal civilian services end up entangled with corruption network [12].

When the existing regulation creates uncertainty, the more severe the effect it faces is the person who does not understand the law. How could they then be asked to obey something they did not even understand? People who do not know can easily be exploited by people who have knowledge and authority over it, in this case, is a prosecutor who can easily threaten the government officials with the threat of corruption, this can lead to bribery to ease the process of implementation of the policy.

After the enactment of the regional autonomy law, there has been a large delegation of authority to the local government. Unfortunately, this is not followed by an increase in the competence of local government apparatus. Several factors indicate;

1. Failure in budget management, in 2015 no less than 282 trillion rupiahs local funds settle in the bank;

2. Errors in the making of local governance rules, over 3000 of local regulation (PERDA) canceled by Minister of Home Affairs;

3. The number of Regional Leads who are entangled in cases of corruption,

Ten of them caught up in corruption cases in 2016 alone by Corruption Eradication

Commission (KPK), where three of them were caught red-handed. This form of incompetence is something that can be prevented, and should not always end up in the realm of Penal Law.

In order to minimize errors in the process of use and management of state finances, especially in the procurement of projects, goods, and services established a body called the Government Procurement Policy Institution (LKPP). The Board aims to further provide a sense of security for civil state apparatus in carrying out the tasks of the state administration primarily in the field of procurement of goods and services. In line with Khi Thai statement that public procurement professionals have paid a great deal of attention to procurement improvements or reform[13].

Not only in the area of procurement of goods and services, but the fear of local state apparatus against the threat of criminal sanctions has also become a national issue in Indonesia. So the President issued Presidential Regulation no. 3 of 2016, which principally instructs all law enforcement officers to examine administrative cases not to prioritize criminal approaches but to prioritize administrative sanctions. 
Where further investigation is required, law enforcement officers need to adhere to the principles of conduct of examination based on general principles of good governance, objective reasons, non-conflict of interest, and goodwill. Therefore, in the case of examination management, the results of the examination can not be published before entering the investigation stage. This is necessary to do because once a person is charged as a suspect of corruption, at the same time, the loss of the suspect determination begins.

One of the cases related to administrative error is the case of the director of the Politeknik Negeri Semarang. The case began when the institution needed a machine for the practical work for its students. Based on these requirements, the auction process is then won by CV Central Aditama worth 6 billion rupiahs. Based on the auction CV Central Aditama is obliged to supply 17 machines that will be used by students of Politeknik Negeri Semarang. However, at the time of delivery of goods, only 14 machines that can be provided by CV Central Aditama. Thus, through a written agreement between the project responsible and the winner of the auction, it is agreed that the payment will be made at the time of delivery of the goods, but the winner of the auction remains obliged to provide the remaining three machines.

This agreement should not be a problem, but unfortunately, before the three goods come, the authorities and auditors find that there is a difference between real goods and procurement plans. Finally, Joko Tri Wardoyo as the caretaker of the procurement arrested and made an unlikely case of corruption crime. Three months after the arrest, the three promised machines arrived, with no problems at all. However, unfortunately, can not change the decision of the prosecutor who considers there has been a procedural error in the process of procurement of goods and services.

In this case, we can see that even if a person does not have evil intentions and motives for committing a criminal act of corruption, as long as there is a procedural error it is still considered a corrupt. If such cases are continuously allowed to occur, then, of course, there will be no state administration apparatus that dares to make policy. That then their actions are nothing more than a robot without feeling and soul, for fear of being criminalized when making creative policies.

This brings us to the third topic, the legal uncertainty related to the state losses is not only about the meaning but also about who or which institution is authorized in determining the presence or absence of state losses in a corruption case. Indonesia, as a country with multiple judicial systems, must use appropriate means of handling corruption cases. Unfortunately, the notion of corruption and maladministration in Indonesia is often confusing. Corruption is regulated in Law no. 31 of 1999 as amended by law No. 20 of 2001, while maladministration entered into the domain of state administration regulated in Law No. 30 of 2014 on Government Administration. Thus corruption is a criminal offense, in which the judicial authority becomes the authority of a state court or a special court of corruption.

On the other hand, maladministration, which is a study material of state administration, should be the authority of the state administrative court. In line with Palmer opinion, which stated that corruption, fraud, and maladministration are eating away at budgets at all levels of government and therefore, at the real economy[14]. This is by the notion of maladministration in Indonesia, which is also by the notion of maladministration in Australia, which states that maladministration is not a crime. So in determining whether or not the element of state loss as one element of corruption is not the authority of the state court or the court of corruption, but the authority of the state administrative court. 
Accordance with the decision of the Constitutional Court No. 25 / PUU-XIV / 2016 abolished the word "can" in Article 2 paragraph 1 of the Corruption Act makes the formulation of corruption offense into material offense rather than formal offense. So that all elements contained in the formulation of the offense must be proven first, including the presence or absence of state losses in the act of state administration. To prove the existence or absence of elements of the state's losses, should be within the domain of state administrative law based on the Lex specialist principle [15]. Since most of the PTUN verdict have difficulties in the execution of decisions for unclear cases or there is a duality of authority between the district court and the Administrative Court. The authority of the Administrative Court for maladministration shall be expressly stated separately from the authority of the General Courts so that its verdicts may be executed in the future.

Because the state administrative officer in implementing his authority is not due to personal will / free will, but in order to carry out the task, it is also necessary to prove whether the loss of state is an individual error or is the result of a state administrative process which requires a state administration official to carry out the results of the administrative process. Already mentioned before, in order to improve and maintain the quality of policies and the exercise of the authorities of state administrators, it is necessary to have internal government controls conducted by the Internal Supervisory Authorities of the Government.

Tests of elements of abuse of authority in Indonesia are divided into several scopes, namely:

a. Authority is a right owned by the Agency and Government Officials or other state officials to make decisions and actions in the administration of the government.

b. Abuse of authority shall be the use of authority by the Governing Body and / or Government Officials in making decisions and / or actions in the administration of government conducted by exceeding authority, confusing authority and / or acting arbitrarily as referred to in Article 17 and Article 18 Undang- Law Number 30 Year 2014 on Government Administration.

c. The request for the assessment of the element of abuse of authority is a written request to the Court to assess whether or not there is an element of abuse of authority committed by the agency and government officials in the decision and action.

Not all authorities can be tested in the administrative court of the state; several provisions limit this authority:

a. The court has the authority to accept, to examine, and to decide whether or not there is an abuse of authority in the decision and action of government officials before the criminal process.

b. The court may only be authorized to accept, to examine and to decide whether or not there is a misuse of authority in decisions and actions of government officials after the results of supervision of the government's internal supervision apparatus.

c. The application is filed with the Court whose jurisdiction covers the place of government officials issuing decisions and conducting action (relative competence).

With the enactment of these rules increasingly, it proves that Indonesia does not have a standard rule on how to determine state losses, especially related to the potential of the state. Thus, the Constitutional Court's decision to remove the word "can" is the right decision to reduce the fear of the state administrative apparatus in exercising its authority. 
Although Indonesia has begun to realize to separate the handling of maladministration and corruption cases, there are still many cases that are not corruptions but maladministration leading to the imposition of penal sanction. To this day, Already eight ministers, two governors of Bank Indonesia, 18 governors, one Four-star general, a fourstar policeman and three three-star, About 40 members of the House of Representatives, and about 200 regents/mayors entered prison. The authors agree that corruption should be eradicated, but the eradication must be done thoroughly, so as not to cause unnecessary casualties and cause fear to the civil apparatus of the country that has good intentions i.e., catching the mouse but not burning the granary.

\section{Conclusion}

As long as there is no standard in determining state losses and how to prove it, and what judicial body is authorized to determine whether or not there is a loss of the state in state administration, the fear of local state apparatus in carrying out its duties and authority will remain. Governments run by officials who are afraid of making a solute policy will not be able to solve their community problems.

\section{Acknowledgments}

This article was funded by a non-tax state revenue research fund of Diponegoro University's Law Faculty in 2017.

\section{References}

[1] A. I. M. Shakeel, "Public procurement and corruption in Bangladesh confronting the challenges and opportunities," J. Public Adm. Policy Res., 2010.

[2] R. Seymour and S. Turner, "Otonomi daerah: Indonesia's decentralisation experiment," New Zeal. J. Asian Stud., 2002.

[3] K. Goeniadhie, "Disharmoni Normatif Hukum Keuangan Negara Dalam Peraturan Perundang-Undangan," J. Huk. Maksigama, vol. XXIX, no. 2, pp. 1-16, 2007.

[4] R. Banakar and M. Travers, "Theory and method in socio-legal research," Oñati international series in law and society. 2005.

[5] M. Adler, "A Socio-Legal Approach to Administrative Justice," Law Policy, 2003.

[6] Y. M. I. Patiro, Diskresi pejabat publik dan tindak pidana korupsi. Bandung: Keni Media, 2012.

[7] C. Murphy, "Lon Fuller and the Moral Value of the Rule of Law," Law Philos., vol. 24, no. 3, pp. 239-262, 2005.

[8] T. Honoré, "The dependence of morality on law," Oxf. J. Leg. Stud., 1993.

[9] S. Rahardjo, Biarkan hukum mengalir : catatan kritis tentang pergulatan manusia dan hukum. Jakarta: Penerbit Buku Kompas.

[10] T. M. Tuanakotta, Menghitung Kerugian Keuangan Negara Dalam Tindak Pidana Korupsi. Jakarta: Salemba Empat, 2009.

[11] B. Irawan, "Diskresi sebagai Tindak Pidana Korupsi: Kajian Kriminologi dan Hukum terhadap Fenomena Pejabat Otoritas," Mimb. Huk., vol. 27, no. 2, pp. 143149, 2011.

[12] E. V. Okhotskii, "The Nature of Corruption and Measures to Combat It," Sociol. 
Res., 2011.

[13] K. V. Thai, "Public procurement re-examined," J. Public Procure., 2001.

[14] M. Palmer, "Records management and accountability versus corruption, fraud and maladministration," Rec. Manag. J., 2000.

[15] R. Hasudungan Sianturi, T. Simatupang, and Rahmayanti, "Calculating financial state losses due to corruption in Indonesia: Financial state losses in whoseeyes?," Mediterr. J. Soc. Sci., 2015. 